\title{
Motivation, Attitude, And Competence of Physical Education Students
}

\author{
Evelyn B. Viva ${ }^{1} \&$ Charis B. Limbo ${ }^{2}$
}

\author{
${ }^{1}$ University of Eastern Philippines, Northern Samar, Philippines \\ ${ }^{1}$ UEP, University Town, Catarman, Northern Samar, Philippines \\ ${ }^{2}$ Institute of Human Kinetics, College of Education, Visayas State University, Philippines \\ Correspondence: Charis B. Limbo, Visayas State University, Visca, Baybay City, Leyte, \\ Philippines. \\ Email: charis.limbo@vsu.edu.ph
}

DOI: $10.53103 /$ cjess.v1i2.9

\begin{abstract}
In education, physical education is the subject that plays a very critical role in educating the whole students. This study investigated the level of motivation, attitude, and competence towards physical education of 4001 st and 2nd-year students at the University of Eastern Philippines. This study utilized a structured survey questionnaire analyzed through simple descriptive statistics, Pearson-r, chi-square, and ANOVA. The results of the study showed a significant relationship between variables as rated by the respondents. There was also a significant difference in motivation among respondents when they are group according to the program. But it does not show any significance to the students for attitude and competence. The results implied that a proposed action plan be implemented to improve students' attitude towards physical education, be them more motivated and highly competent in the subject.
\end{abstract}

Keywords: Motivation, Attitude, Competence, Physical Education

\section{Introduction}

In education, physical education (P.E.) is the subject that plays a very critical role in educating the whole students. It promotes an understanding of the centrality of movements in daily life, aimed at physical literacy and the physical activity disposition of all learners from different levels of education. By nature, P.E. is inclusively suitable to all types of learners and empowers these learners to take responsibility of their ability to live an active lifestyle for healthier lives (CHED Memorandum Order No. 80 series of 2017, 2017). Thus, P.E. is a vital scaffold to produce graduates imbued with values and competence to continuously learn to move and move to learn through physical activity participation (Ginanjar et al., 2019; Wallhead \& Ntoumanis, 2004; Ramadan et al., 2020).

In the Philippine setting, P.E. is one of the core subjects in the $\mathrm{K}$ to 12 Curriculum and one of the two mandated courses offered in tertiary education. At all levels, P.E. 
practitioners are generally concerned with the terms motivation, attitude, and competence. Motivation is a process that accounts for the student's interest and its effect on their behavior (Fletcher \& Silverman, 2017). It also educates the student's mind and body and affects students' academic learning and physical activity patterns. On the other hand, an attitude refers to a set of beliefs developed over time and plays a critical role in the learning process. A positive attitude holds students' different perceptions about their teacher, class, and curriculum and lays the foundation for learning (Bain et al., 2010). Student attitudes towards physical education indicated positive changes in their behavior; thus, they had better control over their enjoyment and interest in P.E. (Underwood, 2005; Subramaniam \& Silverman, 2009). Del pro Lesorado (2011) defined competence as an underlying characteristic of students causally related to their functional and outstanding performance in the class. Student's knowledge, skills and abilities are related to competence associated with the student's performance. Students' motivation, attitude, and competence toward physical education affect students' academic learning and physical activity patterns that will last a lifetime. These are all powerful psychological correlates of an individual's physical activity participation which has implications for the present learning environment within P.E. class (Brustad et al., 2005).

However, researchers found a substantial decline in students' willingness to participate in P.E. in school (Pokrovskaya et al., 2020). P.E. has been unfortunately neglected as a subject of the curriculum by students. In most schools, it has been viewed as a "less important subject " and commonly considered "play" that is not equally essential to other subjects that develop high intellectual skills. That is why P.E. practitioners struggled on how to motivate students (Kretschmann, 2014). Students think P.E. is just like a spare tire for them; if they like to attend classes, they will; if they feel not going, they will not. They do not appreciate the values they can get from the subject. They think that computer games are more exciting and beneficial. If they are present and can execute some of the activities, that is already physical education. Students fail to see the unseen aspects that can be developed through this subject. Subramaniam et al. (2011) also disclosed a decline in attitude scores toward physical education as students grew in grade level. Higher grades had lower mean scores. On the other hand, when students perceive that they are not competent, motivation levels decrease; if students are not presented with a positive environment, their attitudes can be negatively affected (Subramaniam \&Silverman, 2002). Improving the level of motivation, attitude, and competence will likewise enhance the status of P.E. in schools.

Thus, this study aimed to determine the level of motivation, attitude, and competence towards physical education of tertiary P.E. students at the University of Eastern Philippines.

Specifically, this study sought to answer the following:

1. What is the level of motivation of the respondents toward physical education? 
2. What is the level of attitude of the respondents towards physical education?

3. What is the level of competence of the respondents in physical education?

4. Is there a significant relationship between the following:

4.1 Level of motivation and level of attitude;

4.2 Level of motivation and level of competence; and

4.2 Level of attitude and level of competence?

5. Is there a significant difference in the levels of motivation, attitude, and competence in Physical Education when respondents are grouped according to program?

\section{Materials and Methods}

\section{Research Design}

This study utilized the descriptive-correlational method of research that primarily seeks to describe relationships among variables (Colton \& Covert, 2007). It was descriptive because it simply collected information about the existing motivation that influenced college students' attitude and competence in the University of Eastern Philippines. It was correlational since it dealt with the significant relationship between this study's independent and dependent variable.

\section{Research Environment}

This study was conducted in the University of Eastern Philippines (UEP), Catarman, Northern Samar, including its three component campuses: UEP- Catubig, UEPLaoang, and UEP -Pedro Rebadulla Memorial Agricultural College (PRMAC). UEP- main campus is the first state university in the Eastern Visayas, covering 481 hectares composed of ten (10) colleges.

\section{Research Respondents}

The respondents of this study were tertiary students who enrolled in physical education during the second semester at the University of Eastern Philippines, employing an absolute 400. In getting the sample, the researcher used a random number using a statistical book. Stratified sampling of student-respondents was utilized using Slovin's formula in getting the desired number of respondents per program.

\section{Research Instruments}

This study utilized a structured survey questionnaire patterned from BREQ-2 by Markland and Tobin (2004), and Sports Motivation Scale (SMS-28) by Pelletier and Sarrazin (2007) for motivation, Ishee and Smith (2013) for the attitude, and Benzon (2019) for the competence. P.E. Experts from the University of Eastern Philippines validated the 
utilized instruments in Physical Education.

\section{Research Procedure}

Before the study's conduct, a letter asking for permission to conduct the study was sent to the Physical Education Department chairman. Another letter was sent to the selected respondents to ask for their permission to become the study respondents. Data were gathered through questionnaires administered by the researcher and immediately retrieved after being answered by the respondents.

\section{Treatment of the Data}

This study used mean, standard deviation, frequency counts, and percentages to describe the motivation and attitude towards physical education and measure the students' level of competence.

Person-r and Chi-square were used to test the significant relationship between the level of motivation and level of attitude towards P.E.; level of motivation and level of competence of the respondents; level of attitude towards physical education and level of competence of the tertiary P.E. students at the University of Eastern Philippines.

ANOVA was also used to test the difference between the respondents' motivation levels, attitudes, and competence when grouped according to the program.

Moreover, to determine the motivation and attitude towards physical education and the level of competence in physical education, the following scoring and interpretation were used:

Table 1: Scoring and interpretation to determine the respondent's motivation and attitude toward physical education

\begin{tabular}{cccc}
\hline Point Values & Scoring & Interpretation & \\
\hline 4 & $3.26-4.00$ & Very High & SA \\
3 & $2.51-3.25$ & High & A \\
2 & $1.76-2.50$ & Low & D \\
1 & $1.00-1.75$ & Very Low & SD \\
\hline
\end{tabular}

Table 2. Scoring and interpretation to determine the respondent's level of competence in physical education

\begin{tabular}{cccc}
\hline Point Values & Scoring & Interpretation & \\
\hline 4 & $3.26-4.00$ & Highly & HC \\
& & Competent & \\
3 & $2.51-3.25$ & Competent & $\mathrm{C}$ \\
2 & $1.76-2.50$ & Less Competent & LC \\
1 & $1.00-1.75$ & Not Competent & NC \\
\hline
\end{tabular}




\section{Results and Discussion}

Table 3 shows the level of motivation among respondents. It is noted that they have a very high level of motivation in terms of Identified Regulation $(\mathrm{M}=3.40, \mathrm{SD}=0.63)$ and Intrinsic Motivation $(\mathrm{M}=37, \mathrm{SD}=0.63)$. The respondents have very low motivation in terms of Amotivation $(\mathrm{M}=1.57, \mathrm{SD}=0.55)$, which inversely signifies a very high level of motivation. Table 3 also shows a low motivation in External Regulation $(\mathrm{M}=2.24, \mathrm{SD}=$ 0.60 ) inversely interpreted as highly motivated. Both

Amotivation and External regulation questions were in the negative form; thus, they are inversely interpreted. Overall, the level of motivation is High $(\mathrm{M}=2.54, \mathrm{SD}=$ $0.34)$.

Table 3. Level of motivation

\begin{tabular}{llll}
\hline Level of Motivation & Mean & SD & Interpretation \\
\hline Amotivation & 1.57 & 0.55 & Very low \\
External Regulation/ & 2.24 & 0.60 & Low \\
Extrinsic Motivation & & & \\
Introjected Regulation & 2.56 & 0.67 & High \\
Identified Regulation & 3.40 & 0.63 & Very High \\
Intrinsic Motivation & 3.37 & 0.63 & Very High \\
Total & 2.54 & 0.34 & High \\
\hline
\end{tabular}

1.00-1.75 (Very Low)

1.76-2.50 (Low)

$2.51-3.25$ (High)

3.26- 4.00 (Very High)

The results in Table 3 disclosed that the respondents were motivated and appropriately guided by their P.E. teachers, which is vital for physical educators to understand. The teacher then must find ways for the students to appreciate Physical Education subjects. Conversely, if an individual perceives incompetence at an activity, the outcome might continue to depend on external rewards. The results also imply that the respondents are responsible enough in everything they do that they would even feel guilty if they did not perform well in their P.E. subjects.

The study results were contrary to the perceived substantial decline in students' willingness to participate in P.E. and sports in school (Pokrovskaya et al., 2020).

Table 4 highlights the level of attitude among respondents toward physical education. The results revealed that the level of attitude in terms of physical aspect got the highest score $(\mathrm{M}=3.15, \mathrm{SD}=0.17)$ while social aspect got the lowest score $(\mathrm{M}=2.67, \mathrm{SD}=$ 0.59). Overall, the level of attitude $(\mathrm{M}=2.91, \mathrm{SD}=0.37)$ of respondents toward physical education is high. 
Table 4. Level of attitude

\begin{tabular}{cccc}
\hline Level of Attitude & Mean & SD & Interpretation \\
\hline Physical Aspects & 3.15 & 0.71 & High \\
Mental Aspects & 3.09 & 0.49 & High \\
Social Aspects & 2.67 & 0.59 & High \\
Emotional Aspects & 2.88 & 0.47 & High \\
Spiritual Aspects & 3.01 & 0.56 & High \\
Total & 2.91 & 0.37 & High \\
\hline
\end{tabular}

1.00-1.75 (Very Low)

$1.76-2.50$ (Low)

$2.51-3.25$ (High)

3.26- 4.00 (Very High)

The results of the study showed a high level of attitude among respondents toward physical education. The results were accorded to the efforts of the PE teachers in introducing the subject properly to the students. Further, the physical aspect got the highest score because most respondents agreed that PE develops their body in good shape. These students also believe that health and physical fitness were the basic tenets of the subject. On the other hand, the social aspect got the lowest score because students felt embarrassed when performing individually. According to them, anything including dances and sports that involves other people can make them more confident and socially participative. Since students have a strong attitude and enjoyment towards P.E or sports, they will keep themselves updated and participative (Gatchalian \& Limbo, 2021).

Similarly, Subramaniam et al. (2011) concluded that students had moderately positive attitudes toward physical education. Although, a decline in attitude scores as students improved in grade level.

Table 5 presents the level of competence of the respondent toward physical education. The respondents are less competent in the Volleyball Basic Skills ( $M=2.39$, $\mathrm{SD}=0.53)$ and most competent in Rhythmic activities $(\mathrm{M}=2.77, \mathrm{SD}=0.46)$. Overall, the respondents were competent $(\mathrm{M}=2.68, \mathrm{SD}=0.14)$.

Table 5. Level of Competence

\begin{tabular}{cccc}
\hline Level of Competence & Mean & SD & Interpretation \\
\hline $\begin{array}{c}\text { Competence in Rhythmic } \\
\text { Activities }\end{array}$ & 2.77 & 0.46 & Competent \\
Fundamental Dance & 2.59 & 0.61 & Competent \\
Position & & & \\
Team Sports & 2.72 & 0.67 & Competent \\
Volleyball Basic Skills & 2.39 & 0.53 & Less Competent \\
Total & 2.68 & 0.14 & Competent \\
\hline
\end{tabular}


1.00-1.75 (Not Competent)

1.76-2.50 (Less Competent)

2.51-3.25 (Competent)

3.26-4.00 (Highly Competent)

Table 5 implies that the respondents were competent in terms of rhythmic activities and sports skills, although a less competent response from the research respondents regarding practical aspects/skills in volleyball. Only a few students know how to serve the ball; most of them are even afraid to hit the ball, believing that hitting the ball can cause them physical pain. They also felt embarrassed when they could not serve the ball properly, or the ball cannot even cross the net to the other side of the court. On the other hand, table 5 also revealed that the competence in rhythmic activities got the highest competency level. This implies that students were exposed to the different folk dances, and teachers made ways to let them understand the importance of folk dances.

According to Brustad et al. (2005), students' perceived competence is a powerful psychological correlate of youth physical activity. Students attempt to demonstrate their competency in line with what they perceive equates to personal success.

Table 6 highlights the significant relationship between motivation, level of attitude, and level of competence. The relationship between the level of motivation and level of competence (Pearson-r= 0.410), level of attitude, and level of competence (Pearson-r=.252) both have a low correlation but were significantly related. For the relationship between the level of motivation and level of attitude (Pearson$\mathrm{r}=0.371$ ), on the other hand, it was found to have a substantially moderate correlation and significance.

Table 6. Test of relationship between level of motivation and level of attitude, level of motivation and level of competence, level of attitude and level of competence

\begin{tabular}{cccccc}
\hline $\begin{array}{c}\text { Variables/ } \\
\text { Indicators }\end{array}$ & $\begin{array}{c}\text { Pearson- } \\
\mathrm{r}\end{array}$ & $\begin{array}{c}\text { Degree of } \\
\text { correlation }\end{array}$ & $\mathrm{p}$-value & $\begin{array}{c}\text { Decision } \\
\text { on Ho }\end{array}$ & Interpretation \\
\hline $\begin{array}{c}\text { Level of } \\
\text { Motivation and } \\
\text { level of attitude } \\
\text { Level of } \\
\text { motivation and } \\
\text { level of } \\
\text { competence } \\
\text { Level of }\end{array}$ & 0.410 & $\begin{array}{c}\text { Moderate } \\
\text { correlation }\end{array}$ & $0.000^{* *}$ & $\begin{array}{c}\text { Reject } \\
\text { Ho }\end{array}$ & Significant \\
$\begin{array}{c}\text { Competence and } \\
\text { level of attitude }\end{array}$ & 0.371 & $\begin{array}{c}\text { Low } \\
\text { Correlation }\end{array}$ & $0.000^{*}$ & $\begin{array}{c}\text { Reject } \\
\text { Ho }\end{array}$ & Significant \\
\hline
\end{tabular}

0.05 Level of Significance 
Table 6 showed the relationship between variables. For the level of motivation and level of attitude, it was found to have a significant relationship. When the level of motivation is high, then the attitude toward the P.E. subject is expected to be high; thus, it is significant. Whether the motivation comes from the teachers teaching P.E. or from the student themselves depends on the attitude of the teacher and the students towards the subject. Similarly, Marques et al. (2011) said that when students' attitudes and motivation toward physical education are similar, it will yield a better result.

Table 6 also showed the relationship between the level of motivation and level of competence. This can be deduced that motivation affects the competence of the students. The teacher's role in motivating the students play a significant role in developing the competence of the respondents in physical education subject as well as its activities.

Treasure and Roberts (2001) have recommended that students' perception of competence within a physical activity is formed by their motivational orientations and the class climate established by the teacher. This research confirms that though the students are not motivated with the subject per se, the teacher in charge created an environment of fun in learning; thus, their skills in performing simple folk dance and playing the sport are significant.

For the significant relationship between the level of attitude and the level of competence, as shown in Table 6, the aspects mentioned, such as physical, mental, emotional, and spiritual, were considered significant to the students' lives because these aspects developed them holistically. Nevertheless, it does not bear any significance in their social aspect, maybe because they knew each other already because they were even classmates outside physical education subjects. The interaction between them is high; thus, social aspect was considered to be normal to them.

This result validated Rikard and Bandvill's (2006) study that attitudes form our behaviors in numerous ways and define the goals we set, our involvement in activities, and those we decide to stop. This means that students with or without physical activities or out of the physical education classes can still socialize. This explains the result that attitude is significant to make one competent in any area he wishes to.

Table 7 shows the test of difference between variables when grouped according to program. It implies to be significant if the p-values are less than 0.05. However, if the computed p-values are more than 0.05 , it is interpreted as not significant. As shown in table 7 , the null hypothesis for motivation $\left(\mathrm{F}=3.405, \mathrm{p}=0.003^{* *}\right)$ was accepted. Meaning there is a significant difference between motivation among respondents when they are group according to the program. However, for the attitude $(\mathrm{F}=0.805, \mathrm{p}=0.567)$ and competence $(\mathrm{F}=1.112, \mathrm{p}=0.255)$ as gleaned in table 7 , it did not show any significance to the students. 
Table 7. Test of difference in the level of motivation, attitude and competence in physical education when grouped according to program

\begin{tabular}{|c|c|c|c|c|c|c|}
\hline $\begin{array}{ll}\text { Sources } \\
\text { Variation }\end{array}$ & Mean & $\mathrm{SD}$ & $\begin{array}{l}\text { F- } \\
\text { value }\end{array}$ & p-value & $\begin{array}{l}\text { Decision } \\
\text { on Ho }\end{array}$ & Interpretation \\
\hline \multicolumn{7}{|l|}{ Motivation } \\
\hline Agriculture & 2.52 & 0.29 & 3.405 & $0.003 * *$ & Reject & Significant \\
\hline Arts \& Comm. & 2.50 & 0.35 & & & Ho & \\
\hline Business Admin & 2.70 & 0.33 & & & & \\
\hline Education & 2.48 & 0.37 & & & & \\
\hline Engineering & 2.51 & 0.32 & & & & \\
\hline Nursing/Med. & 2.52 & 0.39 & & & & \\
\hline Sciences & 2.49 & 0.35 & & & & \\
\hline \multicolumn{7}{|l|}{ Attitude } \\
\hline Agriculture & 2.88 & 0.33 & 0.805 & 0.567 & Do not & Not \\
\hline Arts \& Comm. & 2.92 & 0.49 & & & Reject & Significant \\
\hline Business Admin & 2.99 & 0.39 & & & Ho & \\
\hline Education & 2.88 & 0.36 & & & & \\
\hline Engineering & 2.91 & 0.34 & & & & \\
\hline Nursing/Med. & 2.93 & 0.43 & & & & \\
\hline Sciences & 2.87 & 0.29 & & & & \\
\hline \multicolumn{7}{|l|}{ Competence } \\
\hline Agriculture & 2.75 & 0.48 & 1.112 & 0.255 & Do not & Not \\
\hline Arts \& Comm. & 2.67 & 0.50 & & & Reject & Significant \\
\hline Business Admin & 2.84 & 0.48 & & & Ho & \\
\hline Education & 2.78 & 0.49 & & & & \\
\hline Engineering & 2.81 & 0.38 & & & & \\
\hline Nursing/Med. & 2.84 & 0.42 & & & & \\
\hline Sciences & 2.69 & 0.46 & & & & \\
\hline
\end{tabular}

0.05 Level of Significance

Table 7 implies that there is a significant difference between motivation among respondents when group according to program. This means that motivation theories in physical education applied to the student respondents are all considered to be significant to them. This in relation to the study made by Deci \& Ryan (2008) Self-Determination Theory (SDT). SDT is a formal theory that defines varied sources of motivation. These students may differ in specialization or majors, but when properly motivated in the subject enrolled, maybe in physical education, then performance, whether academically or physically, is possibly high.

But for the attitude and competence as gleaned in Table 7 do not show any significance to the students. This may be due to the indifference in attitude toward physical activities and motivation towards the physical education subject, as Marques et al. (2011) backed up. 
Also, Martin-Matillas et al. (2010) reveal that adolescents who received social encouragement engaged more in physical activities than their counterparts who received little or no moral support.

\section{Conclusion}

It can be concluded that there was a significant relationship between the level of motivation and level of competence; level of attitude and level of competence; level of motivation and level of attitude as rated by the respondents.

For the difference among the variables, for motivation, the null hypothesis was accepted. Meaning there is a significant difference between motivation among respondents when they are group according to the program. But for the attitude and competence it does not show any significance to the students.

The results implied that a proposed action plan be implemented to enhance and improve the program implementation of physical education activities in the University of Eastern Philippines. It may also inform the national government of the need to improve the implementation of P.E. in the different parts of the country (Artiga et al., 2020). Additionally, it can help improved students' attitude towards physical education, be more motivated and highly competent in the subject.

\section{References}

Artiga, E.,Limbo, B. ,Maningo, L., \& Mamolo, L. (2020). Effects of "Langoy sa Kaluwasan-Learn to Swim" Extension Project to the Swimming Competency of Barangay Emergency Response Personnel. International Journal of Human Movement and Sports Sciences, 8(6), $438-443$. http://dx.doi.org/10.13189/saj.2020.080616

Bain, S., McCallum, R., Bell, S., Sawyer, J., \& Cochran, S. (2010). Foreign Language Learning Aptitudes, Attitudes, Attributions, and Achievement of Postsecondary Students Identified as Gifted. Journal of Advanced Academia, 22, 130-156. http://dx.doi.org/10.1177/1932202X1002200106

Brustad, L.A., Williams., \& Gill. (2005). Positive relationship of physical activity and academic performance. CA: Department of Education

CHED Memorandum No. 80, series of 2017 (2017). https://ched.gov.ph/wpcontent/uploads/2017/11/CMO-No.-80-s.-2017.pdf

Colton, D., \& Covert, R.W. (2007). Designing and constructing instruments for social research and evaluation. John Wiley \& Sons.

Deci, E. L., \& Ryan, R. M. (2008). Self-determination theory: A macrotheory on human motivation, development and health. Canadian Psychology, 49, 182-185.

Del pro Lesorado, F. (2011). Standards of professional competencies required of teachers, general directorate of education, vocational training and learning innovation. Year 2010-2011 (pp. 12-49). Retrieved from http://cfieleon.centros.educa.jcyl.es/sitio/upload/modelo_competencias_profesion 
ales_profesorado\%20_tra ducido.pdf

Fletcher, K., \& Silverman, S. (2017). Student perception of competence and attitude in middle school physical education. https://doi.org/10.18666/TPE-2017-V74-I16557

Gatchalian, F., \& Limbo, C. (2021). Awareness, attitude, and practices on hydration and fluid replacement among coaches of varsity athletes. JIPES - Journal of Indonesian Physical Education and Sport, 7(01), 46-59. http://journal.unj.ac.id/unj/index.php/jipes/article/view/20947G

Ginanjar, A., Suherman, A., Juliantine, T., \& Hidayat, Y. (2019). Sports orientation during learning team or individual sports using a sport education model. Jurnal Cakrawala Pendidikan, 38(2), 377-386. https://doi.org/10.21831/cp.v38i2.24021

Ishee, J \& Smith, C (2004) Attitudes of middle school students. Journal of Physical Education, Recreation \& Dance, 75(3) 5, https://doi.org/10.1080/07303084.2004.10609243

Kretschmann, R. (2014). Student motivation in physical education - The evidence in a nutshell.

Markland, D., \& Tobin, V. (2004). A modification to the behavioral regulation in exercise questionnaire to include an assessment of amotivation. Journal of Sport \& Exercise Psychology, 26, 191-196.

Marques, A., Martins, J., Martins, M., Cista, J., Sarmento, H., \& Carreiro da Costa, F. (2011). The importance of attitudes towards physical activity and its relationship with practice of physical activity. Journal of Sports Medicine, 45 (15), 1-2. https://doi.org/10.1136/bjsports-2011-090606.21

Martin-Matillas, M. Ortega, F.B., Ruiz, J.R., Martinez-Gomez, D., Marcos, A., Moliner-Urdiales, D., Politi, A., Pedrero-Chamizo, R. Beghin, L. Molnar, D., \& Sjostrom, M. (2010). Adolescents physical activity levels and relatives' physical activity engagement and encouragement. European Journal of Public Health, 21 (6), 705-712. https://doi.org/10.1093/eurpub/ckq143

Paulina s. Benson, (2019). Competencies of teachers in relation to the level of implementation and problems of physical education activities in the university of Eastern Philippines system. SSRG International Journal of Economics and Management Studies, 6(1), 135-142.

Pelletier, L., \& Sarrazin, P. (2007). The revised six-factor sport motivation scale (Mallett, Kawabata, Newcombe, Otero-Forero, \& Jackson, 2007): something old, something new, and something borrowed. Psychology of Sport and Exercise, 8, 615e621. http://dx.doi.org/10.1016/j.psychsport.2007.03.006.

Pokrovskaya, T., Usupov, R., Titova, E., \& Zhuravleva, Y. (2020). Distance learning in physical education and sports discipline in terms of self-isolation. Teoriya $i$ Praktika Fizicheskoy Kultury, 11, 65-67.

Ramadan, G., Mulyana, N., Iskandar, D., Juniarti, Y., \& Hardiyanti, W. E. (2020). Physical education for early childhood: The development of students' motor in athletics basic motion. In Proceedings of the 4th International Conference on Sport Science, Health, and Physical Education (ICSSHPE 2019). Paris, France: Atlantis Press. https://doi.org/10.2991/ahsr.k.200214.023

Rikard, G., \& Banville, D. (2006). High school student attitudes about physical 
education. Sport, Education and Society, 11(4), 385-400.

Subramaniam, C. M., \& Silverman, M. (2011). Exploring a model of self-perceptions and social influences in the prediction of adolescent leisure-time physical activity. Journal of Sport and Exercise Psychology, 30, 3-22.

Subramaniam, P.R. (2009). Motivational effects of interest on student engagement and learning in physical education: A review. International Journal of Physical Education, 46 (2), 11-19.

Treasure, K. J., \& Roberts, W. C., (2001). Motivation reconsidered: The concept of competence. Psychological Review, 66, 297-333.

Underwood, J, (2005). Attitude of college students towards physical education and sports. Internat.J. Phy. Edu.,(1),45-52.

Wallhead, T. L., \& Ntoumanis, N. (2004). Effects of a sport education intervention on students' motivational responses in physical education. Journal of Teaching in Physical Education, 23(1), 4-18. https://doi.org/10.1123/jtpe.23.1.4 